\title{
Macrozoobenthos assemblage patterns in European carp (Cyprinus carpio) ponds - the importance of emersed macrophyte beds
}

\author{
Lenka Kajgrova $^{1, *}, Z^{2}$ denek Adamek ${ }^{1}$, Jan Regenda ${ }^{1}$, Christian Bauer $^{2}$, Vlastimil Stejskal ${ }^{1}$, \\ Oldrich Pecha ${ }^{1}$ and David Hlavac ${ }^{1}$ \\ ${ }^{1}$ University of South Bohemia in Ceske Budejovice, Faculty of Fisheries and Protection of Waters, South Bohemian Research Centre \\ of Aquaculture and Biodiversity of Hydrocenoses, Institute of Aquaculture and Protection of Waters, České Budějovice 370 05, Czech Republic \\ ${ }^{2}$ Federal Agency of Water Management, Ecological Station Waldviertel, Gebharts 33, Schrems A-3943, Austria
}

Received: 6 August 2020 / Accepted: 5 February 2021

\begin{abstract}
Qualitative and quantitative differences in benthic macrozoobenthos distribution in carp pond littoral zones (macrophyte areas; LM) and pelagic zones (macrophyte-free areas; MF) were assessed in four commercial carp (Cyprinus carpio) grow-out ponds in the Czech Republic (semi-intensive management) and Austria (organic management) monthly over the growing season (June-September) of 2016 and 2017. While differences in environmental parameters and granulometric composition between LM and MF were statistically non-significant $(p>0.05)$, organic matter content was significantly higher $(p<0.05)$ in LM. Average macrozoobenthos density and biomass in LM (mean 431 ind. $\mathrm{m}^{-2}$ and $6.78 \mathrm{~g} . \mathrm{m}^{-2}$ ) was usually significantly higher $(p>0.05)$ than MF $\left(371\right.$ ind. $\mathrm{m}^{-2}$ and $\left.3.17 \mathrm{~g} . \mathrm{m}^{-2}\right)$. A similar trend was observed for zoobenthos diversity, with LM having a higher diversity (76 taxa) than MF (47 taxa). At the start of the growing season, chironomid density was higher $(p<0.05)$ in muddy MF zones, regardless of management type, while oligochaete density was higher in muddy LM. The density of both groups later declined, such that density was significantly higher $(p>0.05)$ in sandy substrates, regardless of habitat or management type. Our data suggest a significant drop in macrozoobenthos density and biomass compared with historical data, mainly due to new management techniques (fertilisation, supplementary feeding) and intensification (higher stock densities), suggesting that pond management is crucial as regards benthic invertebrate development and diversity. Our results indicate that emersed LM beds positively influence macrozoobenthos performance in carp ponds, potentially making them biodiversity hotspots. Further, LM beds can be regarded as invertebrate harbours, and hence should be protected and encouraged.
\end{abstract}

Keywords: Macroinvertebrates / fishpond / emergent macrophytes

Résumé - Schémas d'assemblage du macrozoobenthos dans les étangs à carpes européennes (Cyprinus carpio) - l'importance des herbiers de macrophytes. Des différences qualitatives et quantitatives dans la distribution du macrozoobenthos benthique dans les zones littorales des étangs à carpes (zones à macrophytes; LM) et les zones pélagiques (zones sans macrophytes; MF) ont été évaluées dans quatre étangs de grossissement de carpes commerciales (Cyprinus carpio) en République tchèque (gestion semi-intensive) et en Autriche (gestion écologique) chaque mois pendant la saison de croissance (juinseptembre) de 2016 et 2017. Alors que les différences de paramètres environnementaux et de composition granulométrique entre LM et MF étaient statistiquement non significatives $(p>0,05)$, la teneur en matière organique était significativement plus élevée $(p<0.05)$ dans LM. La densité moyenne du macrozoobenthos et la biomasse dans LM (moyenne de 431 ind. $\mathrm{m}^{-2}$ et $6,78 \mathrm{~g} . \mathrm{m}^{-2}$ ) étaient généralement significativement plus élevées $(p>0.05)$ que dans MF (371 ind. $\mathrm{m}^{-2}$ et $\left.3,17 \mathrm{~g} . \mathrm{m}^{-2}\right)$. Une tendance similaire a été observée pour la diversité du zoobenthos, LM présentant une diversité plus élevée (76 taxons) que MF (47 taxons). Au début de la saison de croissance, la densité des chironomes était plus élevée $(p<0.05)$ dans les zones MF boueuses, quel que soit le type de gestion, tandis que la densité des oligochètes était plus élevée dans les zones LM boueuses. La densité des deux groupes a ensuite diminué, de sorte que la densité était nettement plus élevée $(p>0.05)$ dans les substrats sableux, quel que soit le type d'habitat ou de gestion. Nos données

\footnotetext{
*Corresponding author: kajgrova@frov.jcu.cz
} 
suggèrent une baisse significative de la densité et de la biomasse du macrozoobenthos par rapport aux données historiques, principalement en raison de nouvelles techniques de gestion (fertilisation, alimentation complémentaire) et de l'intensification (densités de stock plus élevées), ce qui suggère que la gestion des étangs est cruciale en ce qui concerne le développement et la diversité des invertébrés benthiques. Nos résultats indiquent que les herbiers de LM émergéss influencent positivement la performance du macrozoobenthos dans les étangs à carpes, ce qui en fait potentiellement des points chauds de la biodiversité. En outre, les herbiers de LM peuvent être considérés comme des abris pour les invertébrés et doivent donc être protégés et encouragés.

Mots clés : Macroinvertébrés / étang de pisciculture / macrophytes émergents

\section{Introduction}

Ponds built for common carp production probably constitute the largest area of artificial wetland in Europe (Setlikova et al., 2016). Many of these carp ponds were built on the former sites of marshes, swamps and floodplains, which, to a certain extent, predetermines their plant assemblage structure, which is often characterised by a eulittoral zone overgrown with 'hard' emergent vegetation consisting mostly of Phragmites australis and Typha sp. beds (Francova et al., 2019). These shallow littoral areas, overgrown by emergent plant communities, accumulate higher amounts of sedimentary organic matter than deeper, open water areas (Dykyjova and Ulehlova, 1978). In the 1970s, a comprehensive evaluation of littoral zones was performed under the framework of the IBP (International Biological Programme) Wetland Project (Dykyjova and Kvet, 1978), which emphasised their essential role as regards the functioning of carp pond ecosystems and the provision of complex ecosystem services.

As a wetland habitat, littoral macrophyte beds provide many important ecosystem services, particularly as regards biodiversity, nature protection, water retention and mitigation of bank erosion (Cizkova et al., 2019). Further, the aquatic macroinvertebrate community represents an important link in the productivity of lentic systems (James et al., 1998), being an essential link in the food chain of pond ecosystems and one of the most important natural food components in common carp (Cyprinus carpio) nutrition (Weber and Brown, 2009; Rahman et al., 2010). Monitoring of pond environments, therefore, need to focus not only on abiotic factors but also on planktonic and benthic invertebrates, whose abundance and diversity reflect the quality of the pond ecosystem (Dvorak and Imhof, 1998). The qualitative and quantitative composition of the invertebrate component in pond littoral zones can be negatively affected by hydromorphological degradation of the shoreline, which leads to loss of habitat and physical complexity (Strayer and Findlay, 2010; Brauns et al., 2011). As such, littoral invertebrates are considered as bioindicators for assessing the hydromorphological state of ponds and lakes (Moss et al., 2003; Miler et al., 2013), while macroinvertebrates in deeper waters clear of macrophytes are used to assess the pond's trophic status (Saether, 1979).

Submergent and emergent littoral zone vegetation is an integral part of the aquatic environment (Bazzanti et al., 2010). In carp ponds, littoral macrophyte habitats are valuable ecosystem components with high relevance for their appropriate functioning (Francova et al., 2019). The ecotones formed by pond littoral zone vegetation increase local biodiversity compared to open, macrophyte-free areas (Dvorak and Imhof, 1998; Petr, 2000; Wetzel, 2001). Several studies on carp pondshave examined phytophilous invertebrates colonising the stems and leaves of littoral macrophytes (Sychra and Adamek, 2010; Sychra et al., 2010; Setlikova et al., 2016); however, data on macroinvertebrates living in littoral macrophyte substrate and root systems is largely missing. Owing to the high heterogeneity of bottom substrates, obtaining zoobenthos samples in littoral beds can be difficult, not least due to the presence of plant roots and dead parts in various stages of decomposition. As such, sampling of carp pond macrozoobenthos has been almost exclusively carried out in macrophyte-free areas (Lellak, 1969; Matena, 1989), which are more homogeneous than pond littoral zones. Further, qualitative and quantitative macrozoobenthos composition will differ in sediments overgrown by 'hard' emersed plants and macrophyte-free bottoms. While previous studies have provided data on environmental factors influencing the performance of benthic invertebrates in aquatic macrophyte root systems (Sagova et al., 1993; Sagova-Mareckova, 2002a, b; Sagova-Mareckova and Kvet, 2002), these studies were performed in fishless water bodies; hence, while relevant, their conclusions may not compare well with conditions in carp aquaculture ponds. To increase our knowledge of macroinvertebrate community functioning in carp ponds, therefore, we monitored the macrozoobenthos of both macrophyte-free areas (herein MF) and the substrate and root systems of littoral macrophyte areas (herein LM) in a series of carp ponds under either semi-intensive or organic management.

\section{Material and methods}

\subsection{Study sites}

In total, eight on-growing carp ponds were selected for the purposes of this study (Tab. 1), four in the Blatná and Hluboká regions of South Bohemia (Czech Republic; 410-460 m a.s.1.) and four in the Waldviertel region of Niederösterreich (Austria; 639-661 $\mathrm{m}$ a.s.1.). All of the ponds are located in three watersheds (Lomnice, Lužnice and Otava) of the River Vltava drainage area (Fig. 1). The four Austrian fishponds employ organic (ORG) management methods (for details see Adamek et al., 2019; Anton-Pardo et al., 2020), while the Czech fishponds employ conventional (CONV) semi-intensive methods (Tab. 1). Four of the ponds (two Austrian and two Czech) have a muddy (MU) bottom (Neuteich (NEU), Langerteich (LAN), Podsilniční (POD), Šnekl (SNE)), while the other four (Haslauerteich (HAS), Gebhartsteich (GEB), 
Table 1. Stocking rates at the study ponds.

\begin{tabular}{|c|c|c|c|c|}
\hline Pond & Fish species & Category & ind.ha $a^{-1}$ & kg.ha ${ }^{-1}$ \\
\hline \multirow{3}{*}{ NEU/ORG } & $\mathrm{CC}$ & yearling & 1255 & 85.4 \\
\hline & $\mathrm{CL}$ & yearling & 141 & 3.7 \\
\hline & $\mathrm{CC}$ & yearling & 1264 & 148.7 \\
\hline \multirow[t]{2}{*}{ LAN/ORG } & $\mathrm{SL}$ & yearling & 97 & 1.9 \\
\hline & TT & spawner & 23 & 10.6 \\
\hline \multirow{5}{*}{ HAS/ORG } & $\mathrm{CC}$ & two- to three-year-old & 245 & 166.9 \\
\hline & TT & three-year-old & 57 & 13.1 \\
\hline & $\mathrm{CL}$ & yearling & 19 & 0.5 \\
\hline & EL & yearling & 15 & 5.3 \\
\hline & SL & one- to three-year-old & 16 & 4.8 \\
\hline \multirow{2}{*}{ GEB/ORG } & $\mathrm{CC}$ & two- to three- year-old & 208 & 219.8 \\
\hline & TT & three-year-old & 61 & 18.2 \\
\hline $\mathrm{SNE} / \mathrm{CONV}$ & $\mathrm{CC}$ & sac fry & 175000 & \\
\hline \multirow[t]{2}{*}{$\mathrm{POD} / \mathrm{CONV}$} & $\mathrm{CC}$ & two-year-old & 979 & 244.8 \\
\hline & EL & sac fry & 2577 & \\
\hline $\mathrm{PAN} / \mathrm{CONV}$ & $\mathrm{CC}$ & three-year-old & 492 & 369.2 \\
\hline \multirow{2}{*}{ SKA/CONV } & $\mathrm{CC}$ & three-year-old & 704 & 478.5 \\
\hline & EL & yearling & 12 & 2.3 \\
\hline
\end{tabular}

Fish abbreviations: $\mathrm{CC}=$ common carp Cyprinus carpio; $\mathrm{CL}=$ common whitefish Coregonus lavaretus; $\mathrm{TT}=$ tench Tincatinca $\mathrm{EL}=\mathrm{Northern}$ pike Esox lucius; $\mathrm{SL}=$ pikeperch Sander lucioperca. For pond abbreviations see Table 2. Other abbreviations: ORG $=0$ organic management, $\mathrm{CONV}=$ conventional management.

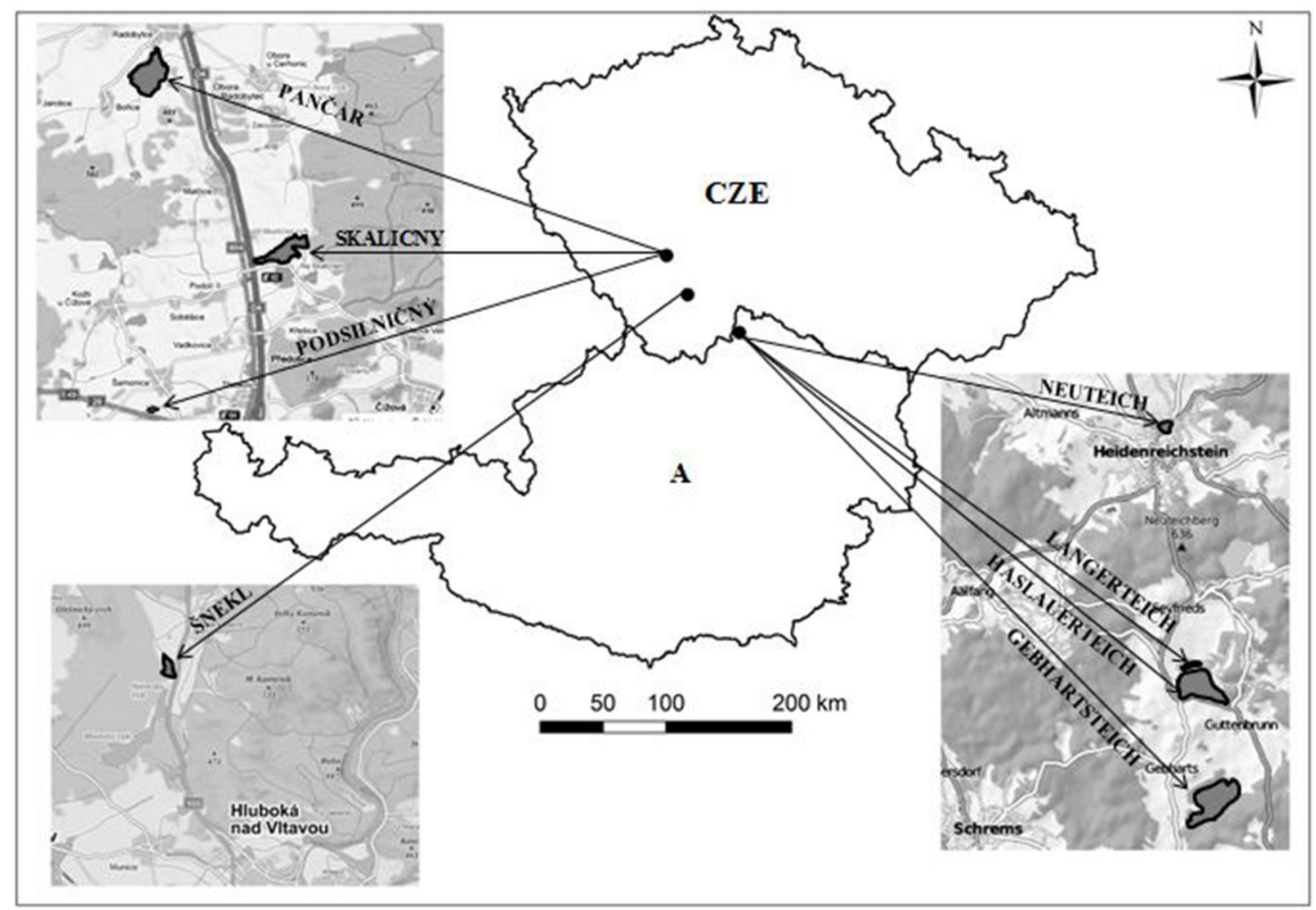

Fig. 1. Location of the ponds used in this study.

Skaličný (SKA) and Pančár (PAN)) are characterised by mostly sandy (SA) bottoms (Tab. 2). All of the ponds have a regularly developed $1-5 \mathrm{~m}$ wide littoral area with emersed vegetation creating an interface between the terrestrial and aquatic zones. The littoral macrophyte belts are mainly comprised of common reed (Phragmites australis), supplemented by patches of cattail (Typha sp.) and watergrass (Glyceria sp.), the whole corresponding to the foederatioPhragmition communis classification provided by Hejny and Husak (1978). 
Table 2. Main characteristics of the eight study ponds.

\begin{tabular}{lllllrll}
\hline Pond name & Abbreviation & Country & No. of samples & Prevailing substrate & Pond area & Management & GPS position \\
\hline Neuteich & NEU & AUT & 40 & muddy & 4.10 & organic & $48.871 \mathrm{~N}, 15.123 \mathrm{E}$ \\
Langerteich & LAN & AUT & 40 & muddy & 2.69 & organic & $48.826 \mathrm{~N}, 15.134 \mathrm{E}$ \\
Haslauerteich & HAS & AUT & 40 & sandy & 48.45 & organic & $48.821 \mathrm{~N}, 15.134 \mathrm{E}$ \\
Gebhartsteich & GEB & AUT & 40 & sandy & 57.00 & organic & $48.799 \mathrm{~N}, 15.138 \mathrm{E}$ \\
Šnekl & SNE & CZE & 30 & muddy & 4.00 & conventional & $49.091 \mathrm{~N}, 14.411 \mathrm{E}$ \\
Podsilniční & POD & CZE & 40 & muddy & 1.94 & conventional & $49.354 \mathrm{~N}, 14.029 \mathrm{E}$ \\
Pančár & PAN & CZE & 40 & sandy & 34.33 & conventional & $49.407 \mathrm{~N}, 14.028 \mathrm{E}$ \\
Skaličný & SKA & CZE & 40 & sandy & 21.45 & conventional & $49.378 \mathrm{~N}, 14.061 \mathrm{E}$ \\
\hline
\end{tabular}

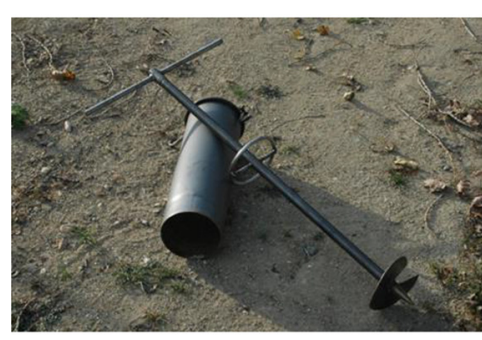

a

b

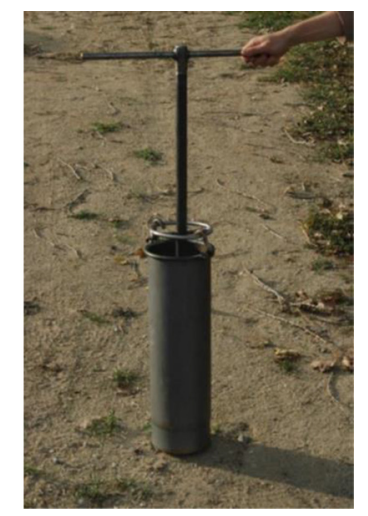

Fig. 2. Drilling core sampler: (a) disassembled before use, (b) assembled and ready to collect a sediment sample.

\subsection{Sampling technique and sample processing}

Physico-chemical environmental indicators were monitored before macrozoobenthos sampling commenced. In each fishpond, five replicates of each variable, that is, oxygen concentration and saturation, temperature (YSI ProODO, YSI Inc./Xylem Inc., USA), pH (YSI 63 meter, YSI Inc./Xylem Inc., USA) and conductivity (EC Testr $11+$, Eutech Instruments Ltd., Singapore), were measured at a depth of $20 \mathrm{~cm}$.

Sampling was performed at monthly intervals during the growing season (May - September) of 2016 and 2017. Five replicate substrate samples were obtained from the LM and MF areasof each pond using a drilling core sampler (Fig. 2; Adamek and Sychra, 2012). Where possible, samples were taken up to a depth of $10 \mathrm{~cm}$ (deeper penetration below this limit was impossible in sandy substrate), with a sample volume of between 1.5 and $2 \mathrm{~L}$, depending on the substrate structure and root density.

Once collected, the samples were preserved in $4 \%$ buffered formaldehyde and, after three-months storage, macroinvertebrates were separated out and placed into three groups, namely Chironomidae, Oligochaeta and Varia (others), which included irregularly or sporadically occurring taxa such as Nematoda, Hirudinea, Mollusca, Isopoda, Acari, Hemiptera, Ephemeroptera, Megaloptera, Odonata, Trichoptera, Coleoptera, Ceratopogonidae, Limoniidae, Tabanidae, Ephydridae, Chaoboridae, Simuliidae and Cecidomyiidae. For each group, density (ind. $\mathrm{m}^{-2}$ ) and biomass $\left(\mathrm{g} \cdot \mathrm{m}^{-2}\right)$ were determined. Invertebrates were determined to lowest possible taxonomical level (mostly species) using common and, when appropriate, updated keys. Samples of bottom substrate were also taken at each locality, again using the drilling core sampler, in order to determine particle size structure (granulometry) and content of organic substance, the latter assessed by loss on ignition.

\subsection{Statistics}

The density of zoobenthos (Oligochaeta and Chironomidae) was calculated for each interaction/factor separately as well as between factors, that is, habitat $(\mathrm{LM} \times \mathrm{MF})$, management $(\mathrm{ORG} \times \mathrm{CONV})$ and substrate $(\mathrm{SA} \times \mathrm{MU})$. Varia were not assessed for density due to their sporadic and irregular occurrence; however, this group was determined to the lowest possible taxa, thus the number of taxa could be compared between habitats (LM and MF). Varia were included into total biomass $\left(\mathrm{g} . \mathrm{m}^{-2}\right)$, thus biomass includes all benthic invertebrates. In order to compare bottom fauna density and biomass, we used factorial analysis of variance (Factorial ANOVA) in the software packages STATISTICA 12 (StatSoft, USA) and Statistix 8.1 (Analytical software, 2003), taking into account different factors such as substrate and/or management. Least significant difference (LSD) at the $5 \%$ level was used for multiple comparison tests between interactions. Differences in environmental variables were assessed using the non-parametric Mann-Whitney U test in STATISTICA 12 (StatSoft, USA). Environmental variables were only measured to assess their suitability for fish and bottom fauna, thus interactions between pond environments were omitted.

\section{Results}

\subsection{Environmental variables}

Briefly, environmental variables did not differ significantly between ponds. While smaller and larger differences were recorded between LM and MF areas, all differences were nonsignificant (Fig. 3). Differences in granulometric composition between the LM and MF area were statistically non-significant $(p>0.05)$. As expected, organic matter content was significantly higher $(p<0.05)$ in LM areas (Tab. 3). 

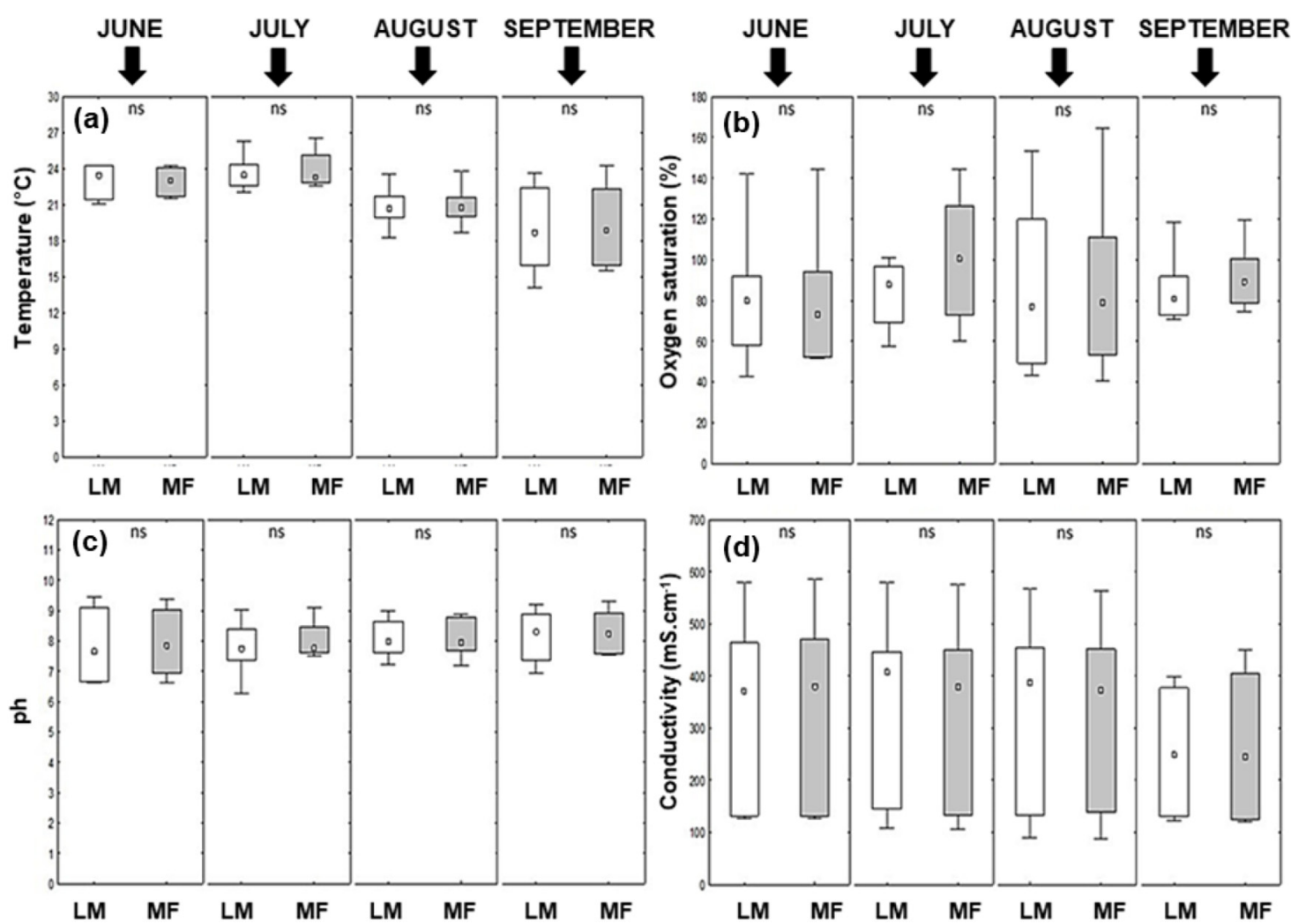

Fig. 3. Box plots for average monthly environmental variable values in the littoral macrophyte (LM) and macrophyte-free (MF) areas: (a) temperature, (b) oxygen saturation (\%), (c) $\mathrm{pH},(\mathrm{d})$ conductivity. Note: central square $=$ median, box $=$ interquartile range, whiskers $=$ non-outlier range $(1.5 \times$ interquartile range $)$, points $=$ outliers, $n s=$ non-significant $(\mathrm{p}>0.05)$.

Table 3. Mean values \pm SD for granulometric composition (\%) and organic matter content $(\%)$ in the littoral macrophyte (LM) and macrophyte-free (MF) areas.

\begin{tabular}{llcl}
\hline Size of grains $(\mu \mathrm{m})$ & LM & MF & $p$ \\
\hline$>3000$ & $13.38 \pm 7.79$ & $9.38 \pm 6.49$ & $\mathrm{~ns}$ \\
$710-3000$ & $32.22 \pm 16.04$ & $32.73 \pm 16.79$ & $\mathrm{~ns}$ \\
$500-709$ & $13.65 \pm 5.02$ & $13.48 \pm 3.37$ & $\mathrm{~ns}$ \\
$250-500$ & $25.43 \pm 12.82$ & $28.28 \pm 11.17$ & $\mathrm{~ns}$ \\
$106-250$ & $12.64 \pm 8.35$ & $13.58 \pm 6.37$ & $\mathrm{~ns}$ \\
$53-106$ & $1.89 \pm 2.07$ & $1.70 \pm 1.54$ & $\mathrm{~ns}$ \\
$<53$ & $0.49 \pm 0.52$ & $0.42 \pm 0.52$ & $\mathrm{~ns}$ \\
Organic matter $(\%)$ & $5.21 \pm 3.55$ & $2.14 \pm 1.43$ & $*$ \\
\hline
\end{tabular}

Note: ns $=$ non-significant, ${ }^{*} p<0.05$.

\subsection{Macrozoobenthos assemblage}

Chironomid density was significantly higher $(p<0.05)$ in the $\mathrm{MF}$ areas in June $\left(\mathrm{LM}=421\right.$ ind. $1^{-1}, \mathrm{MF}=596$ ind. $\left.1^{-1}\right)$, regardless of pond management or substrate; in September, however, chironomid density was significantly higher $(p<0.05)$ in the LM areas $\left(\mathrm{LM}=388\right.$ ind. $^{-1}$, $\mathrm{MF}=171$ ind. $1^{-1}$; Fig. 4a). Oligochaete numbers did not differ significantly $(p>0.05)$ between the LM and MF areas throughout the growing season (Fig. 4b). While there was no significant difference $(p>0.05)$ in the total biomass of benthic invertebrates over the growing season, biomass was usually higher in the LM areas, reaching a maximum in September $\left(11.41\right.$ g.m $\left.{ }^{-2}\right)$ and minimum in August (3.84 g.m ${ }^{-2}$; Fig. 4c). In comparison, highest total biomass in the MF areas was recorded in June (6.20 g. $\mathrm{m}^{-2}$ ) and the lowest in August (1.41 g. $\mathrm{m}^{-2}$; Fig. 4c). When comparing MU and SA substrates in the LM and MF areas, chironomid density was significantly higher in MU in June,whereas non-significantly $(p>0.05)$ in SA in July and significantly higher $(p<0.05)$ in August and September (Fig. 5a). Highest mean oligochaete density was recorded in MU substrate in June and July at LM (1077 and 1085 ind. $^{-1}$, respectively), levels being significantly higher $(p<0.05)$ than MF in July. No significant differences $(p>0.05)$ were recorded in substrate between the MF and LM areas (Fig. 5c). Chironomid density was significantly higher $(p<0.05)$ in LM areas under CONV management in June and September (Fig. 5b), while oligochaete density was higher in both LM and MF areas in ORG ponds (Fig. 5d). Macrozoobenthos biomass was usually slightly higher in LM areas in both MU and SA substrates, except for non-significant $(p>0.05)$ differences in MU substrate in August and September (Fig. 5e). Higher, though non-significant $(p>0.05)$, biomass values were generally recorded in CONV ponds, except for August $(p>0.05)$ and September $(p<0.05)$, when biomass values were higher in ORG ponds at the start of the growing season, though less so over the rest of the season (Fig. 5f). Assessments of mean macrozoobenthos density (ind. ${ }^{-2}$ ) and biomass $\left(\right.$ g.m $\left.^{-2}\right)$, and their interactions with habitat, pond management and substrate, 

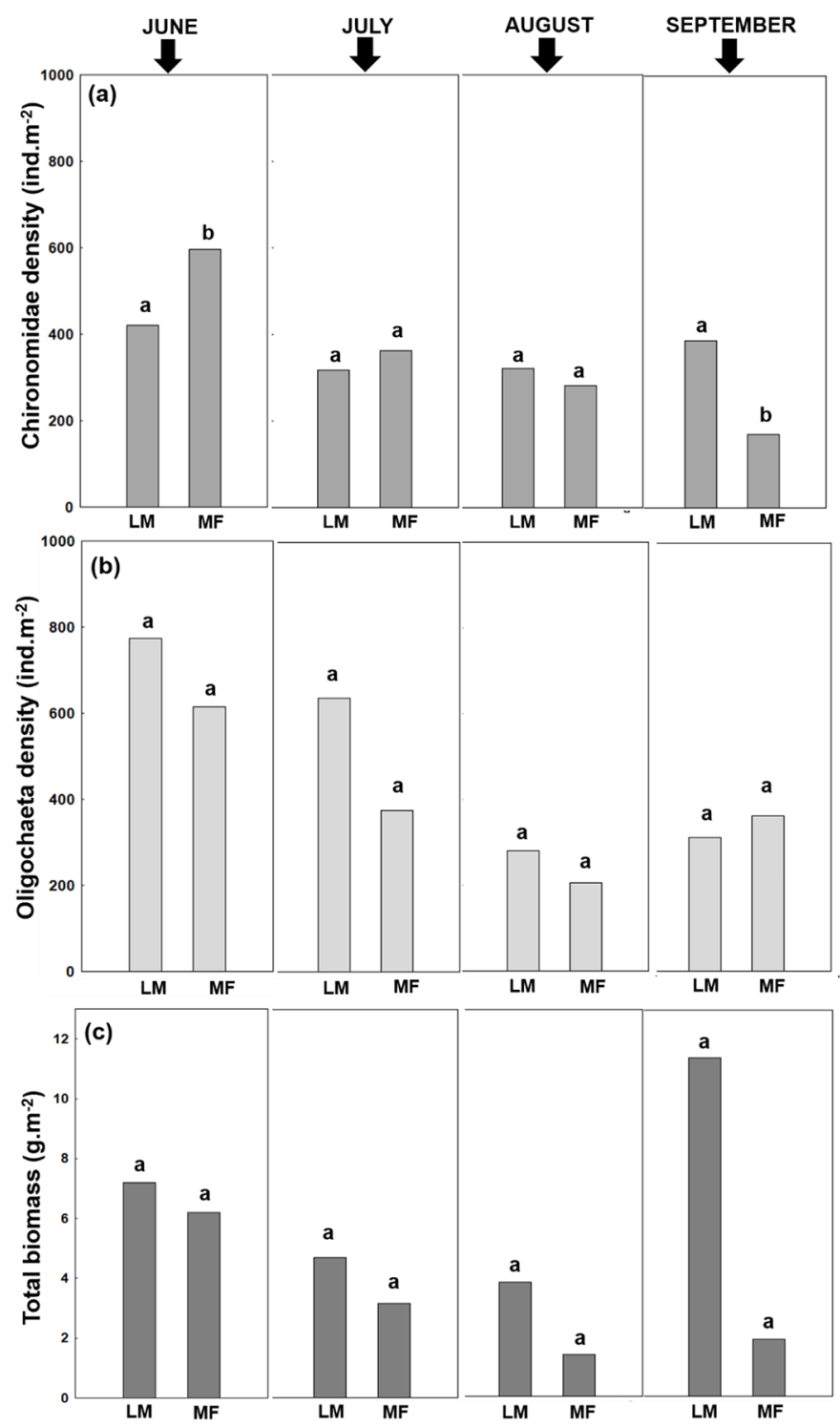

Fig. 4. Macrozoobenthos density (ind. $\mathrm{m}^{-2}$ ) and biomass $\left(\mathrm{g} \cdot \mathrm{m}^{-2}\right)$ in the littoral macrophyte (LM) and macrophyte-free (MF) areas: (a) chironomid density in ind. $\mathrm{m}^{-2}$, (b) oligochaete density in ind. $\mathrm{m}^{-2}$, (c) total biomass in $\mathrm{g} \cdot \mathrm{m}^{-2}$.

showed that chironomid density was mostly higher in MF areas when considering management and substrate, except for MF CONV SA (248 ind. $\left.{ }^{-2}\right)$, where values were significantly lower $(p<0.05)$ than at LM CONV SA (576 ind. ${ }^{-2}$; Tab. 4). Oligochaete density showed the opposite trend, with mean levels mostly higher (though not significantly so) in LM areas in relation to management and substrate, the one exception being in LMORG $\mathrm{SA}$, where mean values were lower than at MF ORG SA. Biomass was generally higher in LM areas (non-significant), except for LM CONV MU (4.14 g.m ${ }^{-2}$ ), which was lower than MF CONV MU $\left(6.24\right.$ g.m $\left.^{-2}\right)$, though again the difference was non-significant $(p>0.05)$.

Altogether, 76 and 47 benthic macroinvertebrate taxa were recorded in the LM and MF areas, respectively. On average, eight (range: 3-17) taxa were recorded in LM and six (3-12) in MF areas per sampling $(p>0.05$; Appendix 1). The corresponding Shannon-Wiener index for the complete dataset showed a higher macrozoobenthos diversity in LM areas (2.958) compared with MF areas (2.461). Tubificids (mostly Tubificidae g. sp., Limnodrilus hoffmeisteri and Tubifex tubifex) and naidids (mainly Bothrioneurumvejdovskyanum, Stylaria lacustris and Ophidonais serpentina) were the dominant benthic invertebrates in both habitats, except for Stylaria which occurred exclusively at LM sites (Appendix 1). The blackworm (Lumbriculus variegatus) was also recorded in higher numbers in LM areas (40.2 ind. on average) than MF areas (4.6 ind.). Chironomids, mainly the subfamilies Chironominae (genera Chironomus, Endochironomus, Glyptotendipes, Polypedilum and others) and Tanypodinae (Procladius sp.), were frequent in both habitats, though there were marked differences in densities recorded. While Glyptotendipes, Microtendipespedellus gr., Synendotendipes and Kiefferulustendipediformes were more abundant in LM areas, Chironomus, Endochironomus and Polypedilum occurred more frequently, or exclusively (Einfeldiadissidens), in MF areas (Appendix 1). Representatives of leeches (Hirudinea: mainly Helobdella stagnalis and Erpobdella octoculata), snails (Gastropoda), the water louse (Asellus aquaticus and Proasellus coxalis), water bugs (Hemiptera: Sigara and others) and aquatic insect larvae (Ephemeroptera, Odonata and Trichoptera)and water beetles (Coleoptera) occurred almost exclusively in LM areas.

\section{Discussion}

\subsection{Environmental variables}

While no significant differences $(p>0.05)$ were recorded in environmental variables between LM and MF areas in the ponds, some of the differences were worth noting. Aside from June (mid-summer), water temperatures, for example, were usually lower in LM areasdue to shading from the emersed vegetation. Similarly, oxygen concentrations and saturation values were also lower over the same period (again, not in June) due to the decomposition of accumulated organic matter, which was significantly higher $(p<0.05)$ in LM areas (Tab. 3$)$. A decrease in $\mathrm{pH}$ and oxygen saturation (Fig. 3) was previously documented by Sychra et al. (2010) in extensive reed beds just one metre from the open water zone, while Ulehlova and Pribil (1978) confirmed that decomposition processes in the pond littoral resulted in an increase in $\mathrm{CO}_{2}$ production, causing a concomitant drop in $\mathrm{pH}$ in relation to the carbonate equilibrium.

\subsection{Macrozoobenthos assemblage}

As the bottom substrate of carp pond macrophyte beds is heavily overgrown with rhizomes, tillers and roots (Fiala, 1978), the quantitative evaluation of macrozoobenthos is methodologically demanding and usually requires laborious manipulation of specialised sampling devices. As a result, most of the few studies that have been undertaken have focused primarily on phytophilic organisms (Korinkova, 1971; Dvorak, 1978; Sychra et al., 2010), that is, those associated 

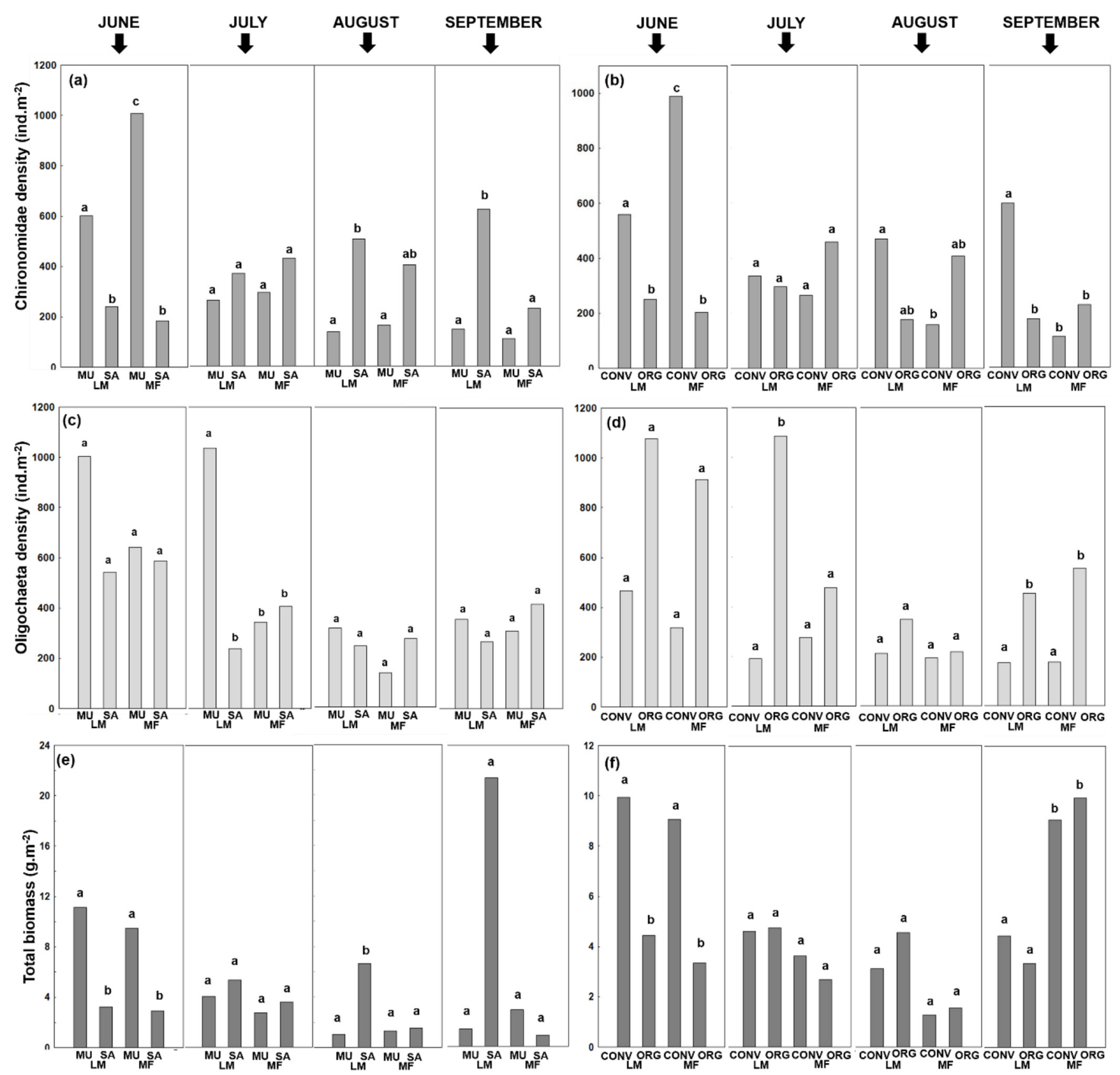

Fig. 5. Macrozoobenthos density (ind. $\mathrm{m}^{-2}$ ) and biomass $\left(\mathrm{g} \cdot \mathrm{m}^{-2}\right.$ ) in the study ponds throughout the sampling period: (a) chironomid density (ind. $\mathrm{m}^{-2}$ ) and (c) oligochaete density (ind. $\mathrm{m}^{-2}$ ) in littoral macrophyte (LM) and macrophyte-free (MF) areas with different substrates $\left(\mathrm{MU}=\right.$ muddy, $\mathrm{SA}=$ sandy), (b) chironomid density (ind. $\mathrm{m}^{-2}$ ) and (d) oligochaete density (ind. $\mathrm{m}^{-2}$ ) in LM and MF areas under different management $\left(\mathrm{ORG}=\right.$ organic, $\mathrm{CO}=$ conventional), (e) macrozoobenthos biomass $\left(\mathrm{g} \cdot \mathrm{m}^{-2}\right)$ in $\mathrm{LM}$ and MF areas with different substrates $\left(\mathrm{MU}=\right.$ muddy, $\mathrm{SA}=$ sandy), (d) macrozoobenthos biomass $\left(\mathrm{g} \cdot \mathrm{m}^{-2}\right)$ in $\mathrm{LM}$ and $\mathrm{MF}$ areas under different management $(\mathrm{ORG}=\mathrm{organic}$, $\mathrm{CO}=$ conventional). Note: All values expressed as means. Means with different superscripts show significant differences between interactions within a taxa group (Chironomidae or Oligochaeta) and month (LSD test, $p<0.05$ ).

with submerged plant stems and leaves between the pond bottom and the water's surface, and have avoided the plant root systems. Sychra et al. (2010), for example, used a benthic sweep net to monitor the density and composition of phytophilic macroinvertebrates living in LM beds close to the bank and close to open water. They found that tubificids (Oligochaeta), leeches (Hirudinea), water mites (Hydrachnidia), corixids (Corixidae) and caddisfly (Trichoptera) larvae (free-swimming and free-moving invertebrates with tracheal gill breathing, ectoparasites, gatherers/collectors and taxa preferring pelal and inorganic substrates) were all more abundant nearer to open waters, while those habitats closer to the shore were characterised by naidids and enchytraeids (Oligochaeta), aquatic snails (Gastropoda), the water louse, aquatic beetles (Coleoptera) and dipteran (Diptera) larvae, representing grazers and scrapers, shredders and invertebrates 
Table 4. Mean macrozoobenthos density (ind. $\mathrm{m}^{-2}$ ) and biomass $\left(\mathrm{g} \cdot \mathrm{m}^{-2}\right.$ ) at the study ponds over the sampling period, with different interactions representing particular ponds.

\begin{tabular}{|c|c|c|c|c|}
\hline \multirow[t]{2}{*}{ Ponds } & \multirow[t]{2}{*}{ Interaction } & \multicolumn{2}{|c|}{ Density (ind. $\mathrm{m}^{-2}$ ) } & \multirow[t]{2}{*}{ Biomass $\left(\mathrm{g} \cdot \mathrm{m}^{-2}\right)$} \\
\hline & & Chironomidae & Oligochaeta & \\
\hline \multirow{3}{*}{ POD, SNE } & $\mathrm{LM}^{*} \mathrm{CO}^{*} \mathrm{MU}$ & $333^{\mathrm{ab}}$ & $92^{\mathrm{a}}$ & $4.14^{\mathrm{a}}$ \\
\hline & $\mathrm{MF}^{*} \mathrm{CO}^{*} \mathrm{MU}$ & $527^{\mathrm{ca}}$ & $85^{\mathrm{a}}$ & $6.24^{\mathrm{ab}}$ \\
\hline & $\mathrm{LM}^{*} \mathrm{ORG}^{*} \mathrm{MU}$ & $212^{\mathrm{b}}$ & $1276^{\mathrm{b}}$ & $3.85^{\mathrm{a}}$ \\
\hline NEU, LANG & $\mathrm{MF}^{*} \mathrm{ORG}^{*} \mathrm{MU}$ & $256^{\mathrm{b}}$ & $683^{\mathrm{c}}$ & $1.84^{\mathrm{a}}$ \\
\hline \multirow[b]{2}{*}{ GEB, HAS } & $\mathrm{LM}^{*} \mathrm{ORG}^{*} \mathrm{SA}$ & $255^{\mathrm{b}}$ & $212^{\mathrm{a}}$ & $14.59^{\mathrm{b}}$ \\
\hline & $\mathrm{MF}^{*} \mathrm{ORG}^{*} \mathrm{SA}$ & $378^{\mathrm{abc}}$ & $445^{\mathrm{ac}}$ & $2.68^{\mathrm{a}}$ \\
\hline \multirow[b]{2}{*}{ PAN, SKA } & $\mathrm{LM}^{*} \mathrm{CO}^{*} \mathrm{SA}$ & $576^{\mathrm{c}}$ & $466^{\mathrm{ac}}$ & $4.40^{\mathrm{a}}$ \\
\hline & $\mathrm{MF}^{*} \mathrm{CO}^{*} \mathrm{SA}$ & $248^{\mathrm{b}}$ & $406^{\mathrm{ac}}$ & $1.78^{\mathrm{a}}$ \\
\hline
\end{tabular}

Means values with different superscripts indicate significant differences (LSD test, $p<0.05$ ) between interactions within a taxa group (Chironomidae and Oligochaeta).

Ponds: $\mathrm{POD}=$ Podsilniční, SNE $=$ Šnekl, NEU = Neuteich, $\mathrm{LANG}=$ Langerteich, GEB $=$ Gebhartsteich, HAS $=$ Haslauerteich, PAN - Pančár, SKA - Skaličný; Habitat: $\mathrm{LM}=$ littoral macrophyte area, $\mathrm{MF}=$ macrophyte-free area. Management: $\mathrm{CO}=\mathrm{conventional}, \mathrm{ORG}=$ organic; Substrate: $\mathrm{MU}=$ muddy, $\mathrm{SA}=$ sandy.

preferring phytal and particulate organic matter microhabitats. Despite only sampling with a benthic sweep net, therefore, Sychra et al. (2010) were able to show that LM areas provide valuable habitat for a wide range of aquatic invertebrate taxa suited to more open-water areas and shallower bankside zones. Nevertheless, this form of sampling ignores another important macroinvertebrate habitat, the roots themselves and the bottom substrate; hence, important data is missed that would affect biomass, diversity and community scores. To address this, we employed a littoral drilling corer that is capable of penetrating the plant root systems and collecting all organisms in the upper $10 \mathrm{~cm}$ layer of muddy substrates. By using this novel approach, we were able to provide the first quantitative data on benthic animals in the substrate of pond macrophyte beds, previous (sporadic) data having been limited mainly to qualitative data.

In two of the few studies to have examined invertebrates in the substrate of pond macrophyte beds, Sagova et al., (1993) and Sagova-Mareckova $(2002 \mathrm{a}, \mathrm{b})$ examined the presence of colonising macroinvertebrates in pond LM areas, based on the premise that the roots of aquatic macrophytes provide oxygen that is subsequently released into the sediment (SagovaMareckova and Kvet, 2002). However, they found that this hypothesis was only strictly true in fishless water bodies. In comparison, the environmental conditions in carp pond littoral zones (both ours and other studies, e.g. Sychra et al., 2010) differed considerably from those of fishless lentic habitats, being typified by lower oxygen concentration and saturation.

In our study, highest oligochaete and chironomid densities were recorded at all sites, regardless of substrate or pond management type, at the beginning of the growing season, that is, June. While biomass values in LM areas increased toward the end of growing season, mainly connected with the growth of aquatic insect larvae, overall macrozoobenthos abundance decreasedslightly, probably connected with increased grazing pressure by carp (see Anton-Pardo et al., 2014) along with the emergence of adult aquatic insect stages (mostly chironomids; Matena, 1989). In a previous study, Dvorak (1978) provided early quantitative figures for pond LM macroinvertebrates, finding a mean density of 20346 ind. $\mathrm{m}^{-2}$ and a biomass of 66.04 g.m $\mathrm{m}^{-2}$, figures many times higher than those in this study. Unfortunately, Dvorak (1978) does not mention the methods used for macroinvertebrate sampling; however, from the species list (dominance of chironomids, absence of oligochaetes) and sampling area description ("inner littoral in contact with fishpond pelagial 1-m distance from open water"), it is highly likely that the data are describing phytophilic invertebrates. Nevertheless, these data emphasise the importance of littoral zones for the production potential and capacity of carp pond ecosystems, as supported by our own data indicating a generally higher macrozoobenthos abundance in pond LM zones (Figs. 4a-c; Tab. 4), most likely associated with poorer fish access and increased cover reducing predation pressure (Sychra et al., 2010) which, in turn, allows them to increase in size over the growing season.

As with the whole agricultural sector, fish farming has undergone significant intensification and diversification of production over the last century. In particular, new technological measureswere brought into carp pond management to enhance fish growth performance, including increased stocking densities, fertilisation, supplementary feeding and liming. These intensification practices, together with the influence of municipal and agricultural runoff and nutrient deposition, has led to a situation where most Czech carp ponds are considered eutrophic, or even hypertrophic (Pechar, 2000). These factors, alongside others, have resulted in lowered macrozoobenthos abundance and diversity, with values now much lower than those recorded in studies from the 1950s to 1970s. Lellak (1957), for example, recorded benthic invertebrate abundances ranging from 5955 to 12400 ind. $\mathrm{m}^{-2}$, while Korinkova (1971) calculated an average annual phytophilic organism density of 6240 ind.m $^{-2}$, significantly more than found in our study in LM areas. Further examination of our data suggests that fish stock and management type are important drivers affecting zoobenthos density and biomass. As shown in Figures 4 and 5, the patterns of carp pond macrozoobenthos density were somewhat ambivalent. In terms of pond management (ORG x CONV), similarly ambiguous results were obtained by Anton-Pardo et al. (2020), who evaluated zooplankton levels alongside macrozoobenthos density and biomass in carp ponds under conventional and 
organic management. Volatility in the density and biomass of macrozoobenthos could be caused by supplementary feeding practices, including where exactly it is provided. Adamek et al. (2016), for example, showed that macrozoobenthos density and biomass were significantly lower at those sites in a pond where feed cereals were dropped. Further, adult carp are commonly benthic feeders, showing a particular preference for chironomid larvae and pupae (Spataru et al., 1980). This leads to a steeper decline in zoobenthos density in MF areas through the growing season as the prey are more easily available to carp grazing than in LM areas (Figs. $4 \mathrm{a}$ and $4 \mathrm{~b}$ ).

\subsection{Importance of aquatic macrophyte beds for macrozoobenthos}

With respect to carp food resources, the macrophyte mesohabitat plays two essential roles in the pond ecosystem, that is, it lowers carp predation pressure (Diehl and Kornijow, 1998) and increases the area colonised by aquatic invertebrates, including their developmental stages and air-breathing adults (Della Bella et al., 2005; Sychra et al., 2010), which provide a rich source of food as they become available at the macrophyte/open water interface (Newman, 1991). In our study, the occurrence of numerous benthic macroinvertebrate taxa was associated exclusively (or almost exclusively) with LM areas. This phenomenon is well known and has been described in various studies dealing with the phytophilic macroinvertebrates colonising macrophytes in pond littoral habitats (e.g. Dvorak and Imhof, 1998; Sychra and Adamek, 2010; Sychra et al., 2010). The plant beds covering the littoral zone of ponds create ecotones, which frequently prove to have biodiversity higher than adjacent terrestrial and aquatic habitats (Pieczynska, 1972; Petr, 2000; Zbikowski and Kobak, 2007), the aquatic macrophytes being colonised by invertebrates as a life substrate, for direct feeding, for periphyton grazing (Soszka, 1975) or as a protection against foraging by fish (Petr, 2000). We also recorded a higher biodiversity of macroinvertebrates colonising the bottom substrate of LM areas compared to the MF pond bottom. It should be noted, however, that these higher diversity figures are not only associated with their direct occurrence on the pond bottom but probably also due to the inclusion of invertebrates from macrophytes during insertion of the sampling apparatus. This latter is probably the cause of the inclusion of such taxa as water bugs (Sigara and Notonecta), water beetles (Donacia, Noterus and others) and possibly some others (e.g. gastropods, mayfly Cloeondipterum, damselflies Coenagrion and Ischnura) in our samples, although their occasional occurrence directly on the bottom cannot be excluded.

\section{Conclusion}

This study provides the first truly quantitative data on the density and biomass of aquatic macroinvertebrates colonising the substrate and root systems in emersed macrophyte beds of the carp pond littoral. Macroinvertebrate density and biomass were generally higher in LM areas than that recorded in MF areas, with biodiversity in particular being significantly higher in the pond LM zone. Substrate and pond management type (CONV vs. ORG) were important driving factors shaping the macrozoobenthos communities observed in this study.
We observed a dramatic drop in macrozoobenthos density and biomass compared with data from the 1950s to 1970 s, primarily due to current management practices linked with production intensification. Our results suggest that emersed LM beds positively influence macrozoobenthosdensity and biomass when they form an integral part of carp pond ecosystems, potentially making them important biodiversity hotspots. Further, LM beds can be regarded as invertebrate harbours, and hence should be protected and encouraged.

\section{Conflict of interest}

The authors declare that they have no conflict of interest.

\section{Supplementary Material}

\section{Supplementary Table S1. Original data zoobenthos.}

The Supplementary Material is available at https://www.kmaejournal.org/10.1051/kmae/2021008/olm.

Acknowledgements. This study was supported by the Ministry of Education, Youth and Sports of the Czech Republic under the CENAKVA Project (No. LM2018099). Thanks are due to Kevin F. Roche (Institute of Vertebrate Biology AS CR) forEnglishproofreading andvaluablecomments to themanuscript.Authors gratefully acknowledge the help of anonymous reviewers whose comments and recommendations considerably contributed to the comprehensibility of the manuscript.

\section{References}

Adamek Z, Mössmer M, Hauber M. 2019. Current principles and issues affecting organic carp (Cyprinus carpio) pond farming. Aquaculture 512: 734261.

Adamek Z, Mrkvova M, Zukal J, Roche K, Mikl L, Slapansky L, Janac M, Jurajda, P. 2016. Environmental quality and natural food performance at feeding sites in a carp (Cyprinus carpio) pond. Aquac Int 24: 1591-1606.

Adamek Z, Sychra J. 2012. Littoral corer. Úřadprumyslovéhovlastnictví ČR, Prague. Utility model No. 24190 (in Czech).

Anton-Pardo M, Hlavac D, Masilko J, Hartman P, Adámek Z. 2014. Natural diet of mirror and scaly carp (Cyprinus carpio) phenotypes in earth ponds. Folia Zool Brno 63: 229-237.

Anton-Pardo M, Hlavac D, Bauer C, Adamek Z. 2020. Environmental and biotic variables in carp (Cyprinus carpio) ponds: organic vs. conventional management. Aquac Int 18: 1-7.

Bazzanti M, Coccia C, Dowgiallo MG. 2010. Microdistribution of macroinvertebrates in a temporary pond of Central Italy: taxonomic and functional analyses. Limnologica 40: 291-299.

Brauns M, Gücker B, Wagner C, Garcia XF, Walz N, Pusch MT. 2011. Human lakeshore development alters the structure and trophic basis of littoral food webs. J Appl Ecol 48: 916-925.

Cizkova H, Vlasakova L, Kvet J. ed. 2019. Wetlands: Ecology, protection and sustainable use. Czech Republic (in Czech): EPISTEME ČeskéBudějovice.

Della Bella V, Bazzanti M, Chiarotti F. 2005. Macroinvertebrate diversity and conservation status of Mediterranean ponds in Italy: water permanence and mesohabitat influence. Aquat Conserv 15: 583-600.

Diehl S, Kornijow R. 1998. Influence of submerged macrophytes on trophic interactions among fish and macroinvertebrates. In: 
Jeppesen E, Søndergaard Ma, Søndergaard Mo, Christoffersen K, eds. The Structuring Role of Submerged Macrophytes in Lakes. New York: Springer Verlag, pp. 24-46.

Dvorak J, Imhof G. 1998. The role of animals and animal communities in wetlands. In Westlake DF, Kvet J, Szczepanski A, eds. The Production Ecology of Wetlands, The IBP Synthesis. Cambridge: Cambridge University Press, pp. 211-318.

Dvorak J. 1978. Macrofauna of invertebrates in helophyte communities. In: Dykyjova D, Kvet J, ed. Pond Littoral Ecosystems, Structure and Functioning, Ecological Studies 28. Berlin, Heidelberg, New York: Springer Verlag, pp. 389-392.

Dykyjova D, Kvet J. ed. 1978. Pond Littoral Ecosystems. Structure and Functioning. Ecological Studies 28. Berlin, Heidelberg, New York: Springer Verlag.

Dykyjova D, Ulehlova B. 1978. Structure and chemistry of the fishpond bottom. In: Dykyjova D, Kvet J, ed. Pond Littoral Ecosystems, Structure and Functioning, Ecological Studies 28. Berlin, Heidelberg, New York: Springer Verlag, pp. 141-152.

Fiala K. 1978. Seasonal development of helophyte polycormones and relationship between underground and aboveground organs. In: Dykyjova D, Kvet J, ed. Pond Littoral Ecosystems, Structure and Functioning, Ecological Studies 28. Berlin, Heidelberg, New York: Springer Verlag, pp. 174-181.

Francova K, Sumberova K, Janauer GA, Adamek Z. 2019. Effects of fish farming on macrophytes in temperate carp ponds. Aquac Int 27: 413-436.

Hejny S, Husak S. 1978. Higher plant communities. In: Dykyjova D, Kvet J, ed. Pond Littoral Ecosystems, Structure and Functioning, Ecological Studies 28. Berlin, Heidelberg, New York: Springer Verlag, 23-64.

James MR, Weatherhead M, Stanger C, Graynoth E. 1998. Macroinvertebrate distribution in the littoral zone of Lake Coleridge, South Island, New Zealand - effects of habitat stability, wind exposure, and macrophytes. NZJ Mar Freshwater Res 32: 287-305.

Korinkova J. 1971 Sampling and distribution of animals in submerged vegetation. Věstník Českoslov Spol Zool 35: 209-221.

Lellak J. 1957. Der Einfluss der Fresstätigkeit des Fischbest and esaufdie Bodenfauna der Fischteiche. Zeitschrift für Fischerei und deren Hilfswissenschaften 8: 621-633.

Lellak J. 1969. There generation-rate of bottom fauna populations of the fish ponds after wintering or summering. Verh Internat Verein Limnol 17: 560-569.

Matena J. 1989. Seasonal dynamics of a Chironomus plumosus (L.) (Diptera, Chironomidae) population from a fish pond in southern Bohemia. Int Rev ges Hydrobiol Hydrogr 74: 599-610.

Miler O, Porst G, McGoff E, Pilotto F, Donohue L, Jurca T, Solimini A, Sandin L, Irvine K, Aroviita J, Clarke R. 2013. Morphological alterations of lake shores in Europe: a multimetric ecological assessment approach using benthic macroinvertebrates. Ecol Indic 34: 398-410.

Moss B, Stephen D, Alvarez C, Becares E, Bund WV, Collings SE, Donk EV, Eyto ED, Feldmann T, Fernandez-Alaez C, Fernandez-Alaez M. 2003. The determination of ecological status in shallow lakesa tested system (ECOFRAME) for implementation of the European Water Framework Directive. Aquat Conserv 13: 507-549.

Newman RM. 1991. Herbivory and detritivory on freshwater macrophytes by invertebrates: a review. J N Am Benthol Soc 10: 89-114.
Pieczynska E. 1972. Ecology of eulittoral zone of lakes. Ekol Polska 20: 637-732.

Pechar L. 2000. Impacts of long-term changes in fishery management on the trophic level water quality in Czech fish ponds. Fish Manag Ecol 7: 23-31.

Petr T. 2000. Interactions between fish and aquatic macrophytes in inland waters. A review. FAO Fisheries Technical Paper 396, FAO, Rome, 185 p.

Rahman MM, Kadowaki S, Balcombe SR, Wahab MA. 2010. Common carp (Cyprinus carpio L.) alters its feeding niche in response to changing food resources: direct observations in simulated ponds. Ecol Res 25: 303-309.

Saether OA. 1979. Chironomid communities as water quality indicators. Ecography 2: 65-74.

Sagova-Mareckova M. 2002a. Distribution of benthic macroinvertebrates in relationship to plant roots, sediment type and spatial scale in fishponds and slow streams. Arch Hydrobiol 156: 63-81.

Sagova-Mareckova M. 2002b. Interactions between crayfish, benthic invertebrates, macrophyte roots and sediment in a littoral zone. Arch Hydrobiol 155: 645-665.

Sagova-Mareckova M, Kvet J. 2002. Impact of oxygen released by the roots of aquatic macrophytes on composition and distribution of benthic macroinvertebrates in a mesocosm experiment. Arch Hydrobiol 155: 567-584.

Sagova M, Adams MS, Butler MG. 1993. Relationship between plant-roots and benthic animals in 3 sediment types of a dimictic mesotrophic lake. Arch Hydrobiol 128: 423-436.

Setlikova I, Blaha M, Edwards-Jonasova M, Dvorak J, Burianova K. 2016. Diversity of phytophilous macroinvertebrates in polycultures of semi-intensively managed fishponds. Limnologica 60: 59-67.

Soszka GJ. 1975. Ecological relations between invertebrates and submerged macrophytes in the lake littoral. Ekol Polska 23: 393-415.

Spataru P, Hepher B, Halev, A. 1980. The effect of the method of supplementary feed application on the feeding habits of carp (Cyprinus carpio L.) with regard to natural food in ponds. Hydrobiologia 72: 171-178.

Strayer DL, Findlay SE. 2010. Ecology of freshwater shore zones. Aquat Sci 72: 127-163.

Sychra J, Adamek Z. 2010. Sampling efficiency of Gerking sampler and sweep net in pond emergent littoral macrophyte beds-a pilot study. Turkish J Fish Aquat Sci 10: 161-167.

Sychra J, Adamek Z, Petrivalska K. 2010. Distribution and diversity of littoral macroinvertebrates within extensive reed beds of a lowland pond. Ann Limnol 46: 281-289.

Ulehlova B, Pribil S. 1978. Water Chemistry in the Fishpond Littorals. In Dykyjova D, Kvet J, eds. Pond Littoral Ecosystems, Structure and Functioning, Ecological Studies 28. Berlin, Heidelberg, New York: Springer Verlag, pp. 126-140.

Weber MJ, Brown ML. 2009. Effects of common carp on aquatic ecosystems 80 years after "carp as a dominant": ecological insights for fisheries management. Rev Fish Sci 17: 524-537.

Wetzel J. 2001. Limnology - Lake and River Ecosystems. San Diego: Academic Press.

Zbikowski J, Kobak J. 2007. Factors influencing taxonomic composition and abundance of macrozoobenthos in extralittoral zone of shallow eutrophic lakes. Hydrobiologia 584: 145-155.

Cite this article as: Kajgrova L, Adamek Z, Regenda J, Bauer C, Stejskal V, Pecha O, Hlavac D. 2021. Macrozoobenthos assemblage patterns in European carp (Cyprinus carpio) ponds - the importance of emersed macrophyte beds. Knowl. Manag. Aquat. Ecosyst., $422,9$. 


\section{Appendix 1: Macroinvertebrate taxa and their mean density (ind. $\mathrm{m}^{-2}$ ) in the study ponds in 2016 and 2017.}

\begin{tabular}{|c|c|c|}
\hline Macroinvertebrate taxa & LM & MF \\
\hline Nematoda sp. & 0.8 & \\
\hline Dero digitata & 2.4 & 6.9 \\
\hline Nais elinguis & 0.5 & 0.4 \\
\hline Ophidonais serpentina & 9.5 & 4.9 \\
\hline Slavina appendiculata & & 0.5 \\
\hline Stylaria & 14.7 & \\
\hline Bothrioneurum vejdovskyanum & 4.8 & 16.3 \\
\hline Psammoryctides barbatus & 0.5 & 17.2 \\
\hline Limnodrilus hoffmeisteri & 43.1 & 47.0 \\
\hline Tubifex tubifex & 50.3 & 37.8 \\
\hline Tubificidae g.sp. & 201.4 & 188.2 \\
\hline Branchiura sowerbyi & 0.9 & 3.4 \\
\hline Lumbriculus variegatus & 40.2 & 4.6 \\
\hline Eiseniella tetraedra & 0.5 & 0.5 \\
\hline Erpobdella octoculata & 19.1 & 3.5 \\
\hline Helobdella stagnalis & 27.8 & 0.8 \\
\hline Alboglossiphonia heteroclita & 2.9 & 0.8 \\
\hline Hemiclepsis marginata & 3.8 & \\
\hline Lymnaea stagnalis & 1.4 & \\
\hline Radix auricularia & 0.5 & \\
\hline Physella acuta & 0.4 & \\
\hline Gyraulus albus & 0.4 & \\
\hline Planorbarius corneus & 0.5 & \\
\hline Musculinum lacustre & 0.9 & 0.4 \\
\hline Cristatella mucedo & + & \\
\hline Asellus aquaticus & 9.2 & 0.4 \\
\hline Proasellus coxalis & 9.6 & 0.8 \\
\hline Eylais sp. & 0.5 & \\
\hline Ranatra linearis & & 0.4 \\
\hline Ilyocoris cimicoides & 1.3 & 0.4 \\
\hline Sigara falleni & 4.3 & 0.4 \\
\hline Sigara sp. juv. & 3.4 & \\
\hline Notonecta sp. juv. & 0.5 & \\
\hline Corixa sp. juv. & 1.0 & 0.5 \\
\hline Cloeon dipterum & 5.1 & 1.2 \\
\hline Caenis lactea & 0.4 & \\
\hline Caenis horaria & 1.9 & \\
\hline Caenis robusta & 0.5 & \\
\hline Sialis lutaria & 0.4 & 0.5 \\
\hline Orthetrum cancellatum & 1.4 & 1.0 \\
\hline Coenagrion sp. & 0.4 & \\
\hline Ischnura elegans & 0.5 & \\
\hline Aeschna sp. juv. & 0.5 & \\
\hline Sialis lutaria & 0.5 & \\
\hline Anabolia furcata & 0.4 & \\
\hline Limnephilus fuscicornis & 1.5 & 0.4 \\
\hline Limnephilus sp. juv. & 0.9 & 0.4 \\
\hline
\end{tabular}

\begin{tabular}{|c|c|c|}
\hline Macroinvertebrate taxa & LM & MF \\
\hline Haliplus sp. larva & 0.5 & \\
\hline Donacia sp. larva & 1.9 & \\
\hline Hyphydrus ovatus & 0.5 & \\
\hline Noterus crassicornis & 0.5 & \\
\hline Noterus sp. larva & 1.4 & \\
\hline Clinotanypus nervosus & 0.4 & 0.4 \\
\hline Chironomus plumosus & 63.8 & 105.4 \\
\hline Chironomus sp. juv. & & 3.9 \\
\hline Endochironomus albipennis & 2.4 & \\
\hline Endochironomus sp. & 9.6 & 16.0 \\
\hline Cryptochironomus cf. obreptans & 2.4 & \\
\hline Cryptochironomus sp. & & 0.5 \\
\hline Parachironomus varus & 0.5 & 0.9 \\
\hline Glyptotendipes barbipes & 7.2 & 1.1 \\
\hline Glyptotendipes sp. & 51.2 & 29.7 \\
\hline Microtendipes pedellus gr. & 15.3 & 5.7 \\
\hline Synendotendipes sp. & 6.8 & 2.3 \\
\hline Paratendipes albimannus gr. & 1.0 & \\
\hline Polypedilum nubeculosum & 18.4 & 31.0 \\
\hline Polypedilum sp. & & 1.1 \\
\hline Procladius sp. & 27.9 & 23.3 \\
\hline Psectrocladius psilopterus gr. & 2.9 & \\
\hline Cricotopus sp. & 4.3 & 1.6 \\
\hline Acricotopus lucens & & 0.5 \\
\hline Ablabesmyia sp. & 0.5 & \\
\hline Kiefferulus tendipediformis & 8.7 & \\
\hline Phaenopsectra sp. & & 2.9 \\
\hline Einfeldia dissidens & & 18.3 \\
\hline Einfeldia $\mathrm{sp}$. & 0.5 & \\
\hline Ceratopogonidae g.sp. & 0.5 & 4.6 \\
\hline Gonomyia sp. & 3.9 & \\
\hline Tabanidae g.sp.juv. & 0.5 & \\
\hline Hydrellia sp. & 0.5 & \\
\hline Chaoborus crystallinus & 9.6 & 2.0 \\
\hline Chaoborus flavicans & 5.8 & 3.7 \\
\hline Simulium noelleri & 0.5 & \\
\hline Ephydridae g.sp. & 4.3 & \\
\hline Cecidomyiidae g.sp. & 1.9 & \\
\hline Total $($ mean \pm SD) & $727 \pm 921^{\mathrm{a}}$ & $594 \pm 616^{\mathrm{a}}$ \\
\hline $\min -\max$ & $263-1126$ & $63-897$ \\
\hline$n$ taxa (total) & 76 & 47 \\
\hline$n$ taxa (mean) & $8^{\mathrm{a}}$ & $6^{\mathrm{b}}$ \\
\hline Min-max & $3-17$ & $3-12$ \\
\hline
\end{tabular}

Note: $\mathrm{LM}=$ littoral macrophyte beds, $\mathrm{MF}=$ macrophyte free areas. Mean values in the same row with different superscripts differ significantly $(p<0.05)$. 